\title{
Synthesis and Molecular Structure of Novel Cyclic Organohydroborate Hafnocene Complex $\left(\eta^{5}-\mathrm{C}_{5} \mathrm{H}_{5}\right)_{2} \mathrm{Hf}\left\{(\mu-\mathrm{H})_{2} \mathrm{BC}_{8} \mathrm{H}_{14}\right\}_{2}$
}

\author{
Jang-Hoon Chung* and Sheldon G. Shore ${ }^{\dagger, *}$ \\ Department of Chemistry, Myongji University, Yongin, Kyunggi 449-728, Korea. *E-mail: chungjh@mju.ac.kr \\ †Department of Chemistry, The Ohio State University, Columbus, OH43210,USA. *E-mail: shore.1@osu.edu \\ Received April 16, 2005
}

Key Words : Metallahydroborate, Cyclic organohydroborate hafnocene

There has been an effort with respect to the investigation of the interaction of boranes with organotransition metal compounds, especially in regard to their role in transition metal catalyzed hydroboration and various $\mathrm{B}-\mathrm{C}$ bond formation reactions. ${ }^{1,2}$ Although a number of metallahydroborate complexes have been studied, ${ }^{3}$ hydroborate derivatives of metallocenes, especially organohydroborate derivatives have received significantly less attention. ${ }^{4,5}$ Only a few early transition metallocene complexes with organohydroborate ligands have been reported. ${ }^{6,7}$ It has been of our interest to prepare the metallocene complex in which the metallocene fragment is bound to the organohydroborate ligand. In principle, the H-B bond could enable organohydroborate coordinate to the metal center through hydrogen bridged bond $\mathrm{M}-\mathrm{H}-\mathrm{B}$.

Relatively recently, we have focused on the chemistry of the early transition metallocene complexes in which cyclic organohydroborate such as $\left[\mathrm{H}_{2} \mathrm{BC}_{8} \mathrm{H}_{14}\right]^{-}$might act as a ligand for the hydrogen bridged complex. ${ }^{8}$ The metallocene complex including two bidentate cyclic organohydroborate ligands has not been previously reported. Here we describe the synthesis and structural characterization of a novel cyclic organohydroborate hafnocene complex $\left(\eta^{5}-\mathrm{C}_{5} \mathrm{H}_{5}\right)_{2} \mathrm{Hf}\{(\mu$ $\left.\mathrm{H})_{2} \mathrm{BC}_{8} \mathrm{H}_{14}\right\}_{2}$ which contains the hydrogen bridged threecenter, two electron bonds Hf-H-B. ${ }^{9}$ To our knowledge this is the first demonstrated example of the unusual 20 electron cyclic organohydroborate group IV metallocene complex which has two bidentate linkages between metal and boron atoms.

\section{Experimental Section}

General Procedures. All manipulations were carried out on a standard high vacuum line or in a drybox under an atmosphere of nitrogen. Diethyl ether, THF, hexane, and toluene were dried over sodium-benzophenone, distilled, and stored in a sealed flask. $\left(\eta^{5}-\mathrm{C}_{5} \mathrm{H}_{5}\right)_{2} \mathrm{HfCl}_{2}$ and $(\mu$ $\mathrm{H})_{2}\left(\mathrm{BC}_{8} \mathrm{H}_{14}\right)_{2}(9$-BBN dimer) were purchased from Aldrich and used as received. Potassium hydride (35\% dispersion in mineral oil) was purchased from Aldrich and was washed with hexane prior to use. $\left.\mathrm{K}_{2} \mathrm{H}_{2} \mathrm{BC}_{8} \mathrm{H}_{14}\right]$ was prepared by literature procedure. ${ }^{10} \mathrm{NMR}$ spectra were recorded on a Bruker AM-250 NMR spectrometer operating at 250.11 $\mathrm{MHz}$, and boron 11 spectrum was externally referenced to
$\mathrm{BF}_{3} \mathrm{OEt}_{2}(\delta$ 0.00). Infrared spectra were recorded on a Mattson Polaris Fourier Transform Spectrometer with 2 $\mathrm{cm}^{-1}$ resolution.

X-ray Structural Determination. Single crystal X-ray diffraction data were collected on an Enraf-Nonius Kappa CCD diffraction system, which employs graphite monochromated Mo $\mathrm{K} \alpha$ radiation $(\lambda=0.71073 \AA)$. A single crystal of $\left(\eta^{5}-\mathrm{C}_{5} \mathrm{H}_{5}\right)_{2} \mathrm{Hf}\left\{(\mu-\mathrm{H})_{2} \mathrm{BC}_{8} \mathrm{H}_{14}\right\}_{2}$ was mounted on the tip of a glass fiber coated with Fomblin oil (pentafluoropolyether), and crystallographic data were collected at $-123{ }^{\circ} \mathrm{C}$. Unit cell parameters were obtained by indexing the peaks in the first 10 frames and refined employing the whole data set. All frames were integrated and corrected for Lorentz and polarization effects using the Denzo-SMN package (Nonius BV, 1999). ${ }^{11}$ The empirical absorption correction was applied using the SORTAV program ${ }^{12}$ provided by MaXus software. ${ }^{13}$ The structure was solved by direct methods and refined using SHELXL-97 (difference electron density calculations and full matrix least-squares refinements) structure solution package. ${ }^{14}$ The hydrogen atoms of $\mathrm{Cp}$ rings and bridge hydrogen atoms were located and refined isotropically. All other hydrogen atoms were calculated and fixed during the refinement.

Preparation of $\left(\eta^{5}-\mathbf{C}_{5} \mathbf{H}_{5}\right)_{2} \mathbf{H f}\left\{\left(\mu-H_{2}\right)_{2} \mathbf{B C}_{8} \mathbf{H}_{14}\right\}_{2}$. In the drybox $379.6 \mathrm{mg}(1.0 \mathrm{mmol})$ of $\left(\eta^{5}-\mathrm{C}_{5} \mathrm{H}_{5}\right)_{2} \mathrm{HfCl}_{2}$ and 320.2 $\mathrm{mg}(2.0 \mathrm{mmol})$ of $\mathrm{K}\left[\mathrm{H}_{2} \mathrm{BC}_{8} \mathrm{H}_{14}\right]$ were put into a flask. After degassing, $30 \mathrm{~mL}$ of diethyl ether was transferred into the flask at $-78{ }^{\circ} \mathrm{C}$. The solution was warmed to room temperature and stirred for two days. During the process the solution turned cloudy due to the formation of $\mathrm{KCl}$ which was removed by filtration. A white solid was obtained upon removal of the solvent under vacuum. The solid was redissolved in toluene for crystallization. $361 \mathrm{mg}(65 \%$ yield) of $\left(\eta^{5}-\mathrm{C}_{5} \mathrm{H}_{5}\right)_{2} \mathrm{Hf}\left\{(\mu-\mathrm{H})_{2} \mathrm{BC}_{8} \mathrm{H}_{14}\right\}_{2}$ was obtained. ${ }^{1} \mathrm{H}$ NMR $\left(\mathrm{C}_{6} \mathrm{D}_{6}, 30{ }^{\circ} \mathrm{C}\right) 5.55(\mathrm{~s}), 2.11-1.44$ (br m), -2.56 (br s), -3.37 (br s); ${ }^{11} \mathrm{~B}$ NMR $\left(\mathrm{C}_{6} \mathrm{D}_{6}, 30{ }^{\circ} \mathrm{C}\right) 27.26$ (br s) ppm; IR (KBr) 2982(m), 2915(vs), 2871(vs), 2841(vs), 2027(m), 1661(m), 1470(m), 1437(s), 1410(s), 1315(s), 1207(m), 1043(m), 818(vs) $\mathrm{cm}^{-1}$.

\section{Results and Discussion}

In the reaction of $\mathrm{K}\left[\mathrm{H}_{2} \mathrm{BC}_{8} \mathrm{H}_{14}\right]$ with the electron deficient 16 electron metal center of hafnocene dichloride, the cyclic 
organohydroborate hafnocene complex $\left(\eta^{5}-\mathrm{C}_{5} \mathrm{H}_{5}\right)_{2} \mathrm{Hf}\{(\mu$ $\left.\mathrm{H})_{2} \mathrm{BC}_{8} \mathrm{H}_{14}\right\}_{2}$ is formed (reaction 1). The unusual hafnocene complex has two bidentate cyclic organohydroborate ligands and the hafnium atom is associated with 20 valence electrons. The complex is white solid, stable at room temperature under

$$
\begin{gathered}
\left(\eta^{5}-\mathrm{C}_{5} \mathrm{H}_{5}\right)_{2} \mathrm{HfCl}_{2}+2 \mathrm{~K}\left[\mathrm{H}_{2} \mathrm{BC}_{8} \mathrm{H}_{14}\right] \\
\left(\eta^{5}-\mathrm{C}_{5} \mathrm{H}_{5}\right)_{2} \mathrm{Hf}\left\{(\mu-\mathrm{H})_{2} \mathrm{BC}_{8} \mathrm{H}_{14}\right\}_{2}+2 \mathrm{KCl}
\end{gathered}
$$

vacuum or a nitrogen atmosphere while decomposition occurs when it is exposed to air. In solution, the complex is soluble in THF, diethyl ether, and toluene. Over time ( $c a .60$ min), THF solution of the complex decomposes at room temperature to form $(\mu-\mathrm{H})_{2}\left(\mathrm{BC}_{8} \mathrm{H}_{14}\right)_{2}$ (9-BBN dimer).

The molecular structure of the complex was determined from a single crystal X-ray diffraction analysis. Crystallographic data and selected bond distances and bond angles are given in Tables 1 and 2 , respectively. The molecular structure is shown in Figure 1. The molecular structure contains a crystallographic two-fold axis. The structure of the complex consists of $\left(\eta^{5}-\mathrm{C}_{5} \mathrm{H}_{5}\right)_{2} \mathrm{Hf}$ fragment bound to two cyclic organohydroborate ligands $(\mu-\mathrm{H})_{2} \mathrm{BC}_{8} \mathrm{H}_{14}$ through two hydrogen bridges. The geometry around the metal in the complex can be described as a distorted tetrahedron consisting of a coordination sphere of two $\mathrm{B}$ atoms and the centroids of the two $\mathrm{Cp}$ rings. The $\mathrm{Cp}_{\text {centroid }}-\mathrm{Hf}-\mathrm{Cp}_{\text {centroid, }} \mathrm{B}-$

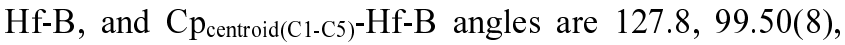
and $101.9^{\circ}$, respectively, and $\mathrm{Hf}-\mathrm{Cp}_{\text {centroid(C1-C5) }}$ distance is 2.207(1) $\AA$. These angles and distance are generally in agreement with those observed for other $\left(\eta^{5}-\mathrm{C}_{5} \mathrm{H}_{5}\right)_{2} \mathrm{Hf}$ systems. ${ }^{15}$ The smaller $\mathrm{C} \mathrm{p}_{\text {centroid }}-\mathrm{Hf}-\mathrm{C} \mathrm{p}_{\text {centroid }}$ angle results from the steric bulk of the cyclic organohydroborate ligands.

The bridge hydrogens of Hf-H-B bonds were located and the position and isotropic thermal parameters were refined. Hf-B, Hf-H(H1B), Hf-H(H2B), B-H(H1B), and B-H(H2B) distances are 2.5781(18), 2.049(17), 2.01(2), 1.186(17), and 1.22(2) Å, respectively. Hf-B-H(H1B), Hf-B-H(H2B), B-

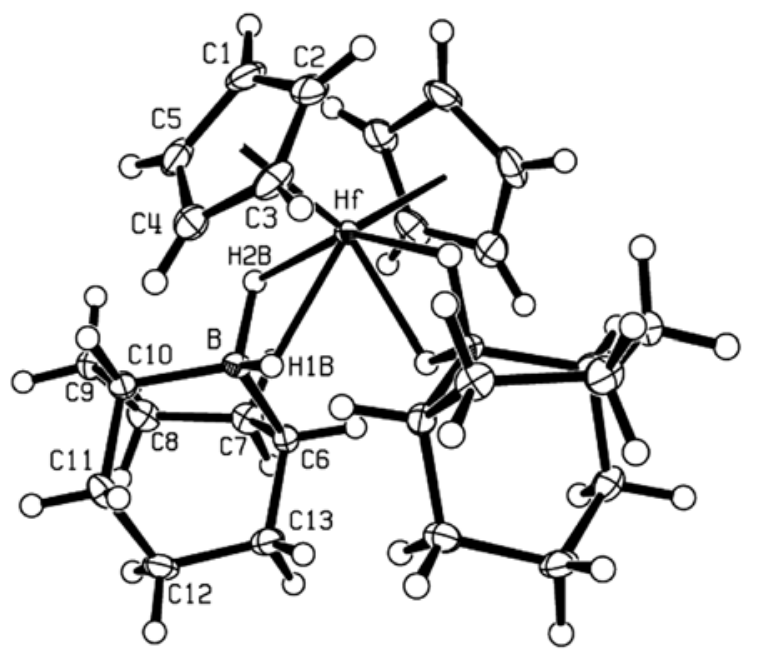

Figure 1. Molecular structure of $\left(\eta^{5}-\mathrm{C}_{5} \mathrm{H}_{5}\right)_{2} \mathrm{Hf}\left\{(\mu-\mathrm{H})_{2} \mathrm{BC}_{8} \mathrm{H}_{14}\right\}_{2}$ with $50 \%$ probability thermal ellipsoids.
Table 1. Crystallographic Data for $\left(\eta^{5}-\mathrm{C}_{5} \mathrm{H}_{5}\right)_{2} \mathrm{Hf}\left\{(\mu-\mathrm{H})_{2} \mathrm{BC}_{8} \mathrm{H}_{14}\right\}_{2}$

\begin{tabular}{ll}
\hline empirical formula & $\mathrm{C}_{26} \mathrm{H}_{42} \mathrm{~B}_{2} \mathrm{Hf}$ \\
$\mathrm{fw}$ & 554.71 \\
space group & $\mathrm{C} 2 / \mathrm{c}$ \\
$\mathrm{a}, \AA$ & $19.183(2)$ \\
$\mathrm{b}, \AA$ & $9.2130(10)$ \\
$\mathrm{c}, \AA$ & $13.9360(10)$ \\
$\beta$, deg & $110.106(4)$ \\
$\mathrm{V}, \AA^{3}$ & $2312.9(4)$ \\
$\mathrm{Z}$ & 4 \\
$\rho$ (calcd), g/cm & \\
$\mathrm{T},{ }^{\circ} \mathrm{C}$ & 1.593 \\
$\lambda, \AA$ & -123 \\
$\theta$ range (deg) & $\mathrm{Mo} \mathrm{K} \alpha(0.71073)$ \\
$h k l$ ranges & $2.48-27.50$ \\
& $-2424,-1111,-1818$ \\
Reflections collected & \\
Independent reflections & 22209 \\
$\mu$, mm & \\
$\mathrm{GOF}^{-1}$ & 2643 \\
$R_{1}[\mathrm{I}>2 \sigma(\mathrm{I})]^{a}$ & 4.521 \\
$\mathrm{w} R_{2}\left(\right.$ all data) ${ }^{b}$ & 1.077 \\
\hline
\end{tabular}

${ }^{a} R_{1}=\Sigma\left\|\mathrm{F}_{\mathrm{o}}|-| \mathrm{F}_{\mathrm{c}}\right\| / \Sigma\left|\mathrm{F}_{\mathrm{o}}\right|$.

${ }^{b} \mathrm{w} R_{2}=\left\{\Sigma \mathrm{w}\left(\mathrm{F}_{\mathrm{o}}^{2}-\mathrm{F}_{\mathrm{c}}^{2}\right)^{2} / \Sigma \mathrm{w}\left(\mathrm{F}_{\mathrm{o}}^{2}\right)^{2}\right\}^{1 / 2}$.

Table 2. Selected bond distances $(\AA)$ and angles $\left({ }^{\circ}\right)$ for $\left(\eta^{5}-\mathrm{C}_{5} \mathrm{H}_{5}\right)_{2} \mathrm{Hf}\left\{(\mu-\mathrm{H})_{2} \mathrm{BC}_{8} \mathrm{H}_{14}\right\}_{2}$



Figure 2. ${ }^{1} \mathrm{H}$ NMR spectrum of $\left(\eta^{5}-\mathrm{C}_{5} \mathrm{H}_{5}\right)_{2} \mathrm{Hf}\left\{(\mu-\mathrm{H})_{2} \mathrm{BC}_{8} \mathrm{H}_{14}\right\}_{2}$.

H(H1B)-Hf, and B-H(H2B)-Hf are 50.9(8), 49.6(9), 102(1), and $103(1)^{\circ}$, respectively. These distances and angles fall within the ranges previously observed for other systems with bidentate Hf-H-B bridges. ${ }^{16,17}$ 
The proton and ${ }^{11} \mathrm{~B}$ NMR spectra are in accord with the solid-state structure determined by the single crystal X-ray analysis. This organohafniumhydroborate complex has two four-membered $\mathrm{Hf}(\mu-\mathrm{H})_{2} \mathrm{~B}$ rings, in which each $\mathrm{Hf}-\mathrm{H}-\mathrm{B}$ bridge is an electron-deficient three-center two electron bond. ${ }^{18}$ In the ${ }^{1} \mathrm{H}$ NMR spectrum of the complex as shown in Figure 2, two inequivalent bridging hydrogens give rise to two broad signals at -2.56 and $-3.37 \mathrm{ppm}$ that fall within the range observed for the bridging hydrogens of other hydroborate early transition metallocene complex. ${ }^{19}$ The proton resonances appear as broad signals since they are bonded to the quadrupolar ${ }^{11} \mathrm{~B}$ nucleus and the two signals are assigned to the Hf-H-B bridging hydrogens. ${ }^{20,21}$ The chemical shifts are typical low-field chemical shifts for early transition metal complexes with $\mathrm{d}^{0}$ configuration. The ${ }^{11} \mathrm{~B}$ resonance is a broad signal that occurs at $27.26 \mathrm{ppm}$ which narrows upon proton decoupling. This is indicative of the presence of Hf-H-B bridge.

Acknowledgement. This work was supported by grant No. 2001-2-12200-001-2 from the Basic Research Program of the Korea Science \& Engineering Foundation.

Supplementary material. Crystallographic data for structural analysis have been deposited with the Cambridge Crystallographic Data Center (CCDC No. 263958). Copy of this information may be obtained free of charge from The Director, CCDC, 12 Union Road, Cambridge CB2 1EZ, UK (Fax: +44-1223-336033; e-mail: deposit@ccdc.cam.ac.uk or www: http://www.ccdc.cam.ac.uk).

\section{References}

1. (a) Burgess, K.; Ohlmeyer, M. Chem. Rev. 1991, 91, 1179. (b) Beletskaya, I.; Pelter, A. Tetrahedron 1997, 53, 4957.

2. Irvine, G. J.; Lesley, M. J. G.; Marder, T. B.; Norman, N. C.; Rice, C. R.; Robins, E. G.; Roper, W. R.; Whittell, G. R.; Wright, L. J. Chem. Rev. 1998, 98, 2685.

3. (a) Marks, T. J.; Kolb, J. R. Chem. Rev. 1977, 77, 263. (b) Xu, Z.; Lin, Z. Coord. Chem. Rev. 1996, 156, 139. (c) Ephritikhine, M. Chem. Rev. 1997, 97, 2193. (d) Lee, J.-D.; Kim, B. Y.; Lee, C.; Lee, Y.-J.; Ko, J.; Kang, S. O. Bull. Korean Chem. Soc. 2004, 25, 1012.

4. (a) Lappert, M. F.; Singh, A.; Atwood, J. L.; Hunter, W. E. J. Chem. Soc., Chem. Commun. 1983, 206. (b) Mancini, M. Inorg.
Chem. 1984, 23, 1072. (c) Zanella, P. Inorg. Chim. Acta 1988, 144, 129.

5. (a) Liu, F.-C.; Liu, J.; Meyers, E. A.; Shore, S. G. Inorg. Chem. 1999, 38, 2169. (b) Liu, F.-C.; Plecnik, C. E.; Liu, J.; Meyers, E. A.; Shore, S. G. J. Organomet. Chem. 2001, 627, 109. (c) Liu, F.C.; Liu, J.; Meyers, E. A.; Shore, S. G. J. Am. Chem. Soc. 2000, 122,6106

6. (a) Plecnik, C. E.; Liu, F.-C.; Liu, S.; Liu, J.; Meyers, E. A.; Shore, S. G. Organometallics 2001, 20, 3599. (b) Liu, S.; Liu, F.-C.; Renkes, G.; Sheldon, S. G. Organometallics 2001, 20, 5717. (c)Antelmann, B.; Chisholm, M. H.; Iyer, S. S.; Huffman, J. C.; Navarro-Llobert, D.; Pagel, M.; Simonsich, W. J.; Zhong, W. Organometallics 2001, 34, 3159.

7. Liu, F.-C.; Liu, J.; Meyers, E. A.; Shore, S. G. Inorg. Chem. 1998, 37, 3293.

8. Jordan, G. T.; Liu, F.-C.; Shore, S. G. Inorg. Chem. 1997, 36, 5597.

9. Baker, R. T.; Ovenall, D. W.; Calabrese, J. C.; Westcott, S. A.; Taylor, N. J.; William, I. D.; Marder, T. B. J. Am. Chem. Soc. 1990, 112, 9399.

10. Köster, R.; Seidel, G. Inorg. Synth. 1983, 22, 198.

11. Otwinowski, Z.; Minor, W. In Methods in Enzymology; Carter, C. W., Jr., Sweet, R. M., Eds.; Academic Press: New York, 1997; Vol. 276(A), p 307.

12. (a) Blessing, R. H. Acta Crystallogr., Sect. A 1995, 51, 33. (b) Blessing, R. H. J. Appl. Crystallogr. 1997, 30, 421.

13. Mackay, S.; Gilmore, C. J.; Edwards, C.; Tremayne, M.; Stuart, N.; Shankland, K. MaXus: A Computer Program for the Solution and Refinement of Crystal Structures from Diffraction Data; University of Glasgow: Scotland; Nonius BV: Delft, The Netherlands and Mac-Science Co. Ltd.: Yokohama, Japan, 1998.

14. Sheldrick, G. M. SHELXL-97: A Structure Solution and Refinement Program; University of Göttingen: Germany, 1998.

15. Joseph, S. C. P.; Cloke, F. G. N.; Cardin, C. J.; Hitchcock, P. B Organometallics 1995, 14, 3566 .

16. (a) Makhaev, V. D. Russ. Chem. Rev. 2000, 69, 727. (b) Joseph, S C. P.; Cloke, F. G. N.; Cardin, C. J.; Hitchcock, P. B. Organometallics 1995, 14, 3566 .

17. (a) Ding, E.; Liu, F.-C.; Liu, S.; Meyers, E. A.; Shore, S. G. Inorg. Chem. 2002, 41, 5329. (b) Liu, F.-C.; Liu, J.; Meyers, E. A.; Shore, S. G. J. Am. Chem. Soc. 2000, 122, 6106.

18. Ho, N. N.; Bau, R.; Plecnik, C.; Shore, S. G.; Wang, X.; Schultz, A. J. J. Organomet. Chem. 2002, 654, 216.

19. Chen, X.; Liu, S.; Plecnik, C.; Liu, F.-C.; Fraenkel, G.; Shore, S. G. Organometallics 2003, 22, 275.

20. James, B. D.; Nanda, R. K.; Wallbridge, M. G. H. Inorg. Chem. 1964, 3, 1798

21. (a) Frost, P. W.; Howard, J. A. K.; Spencer, J. L. J. Chem. Soc., Chem. Commun. 1984, 1362. (b) Baker, M. V.; Field, L. D. J. Chem. Soc., Chem. Commun. 1984, 996. (c) Esteruelas, M. A.; Jean, Y.; Lledos, A.; Oro, L. A.; Ruiz, N.; Volatron, F. Inorg. Chem. 1994, 33, 3609. 